\title{
A simple and reliable tool to quantify calcium burden of ascending aorta
}

\author{
E Gatta ${ }^{1}$, G Rescigno ${ }^{2 *}$, V Polverini ${ }^{3}$, MD Pierri ${ }^{2}$, L Carbonari ${ }^{1}$, A Giovagnoni ${ }^{3}$, L Torracca ${ }^{2}$ \\ From 23rd World Congress of the World Society of Cardio-Thoracic Surgeons \\ Split, Croatia. 12-15 September 2013
}

\section{Background}

Ascending aorta calcific plaques represent a potential source of emboli during open-heart procedures. The aim of our study was to validate a simple and new technique to quantify aorta calcium burden.

\section{Methods}

Ten thoracic CT scans (TCMD General Electric LightSpeed VCT 64 Slices) of octogenarian subjects were analysed by two radiologists and one vascular surgeon, using the Osirix Pro Software. A 3D reconstruction of the ascending thoracic aorta was obtained from the annular plane to the origin of the innominate trunk. The outer curvature maximal length was measured; therefore this value was divided by ten Region Of Interest (ROI) points. At each ROI an exact perpendicular section of the aorta was obtained, whose calcium involvement was expressed as a percentage. The overall calcium burden was expressed as the mean of the ten measurements.

\section{Results}

Cronbach test estimate was 0.975 . Intraclass correlation coefficient (ICC) was 0.927 (95\% confidence limits = $0.904-0.946)$ with $\mathrm{F}$ test $=39.3$ and $\mathrm{p}<0.001$.

\section{Conclusion}

Our technique represents a simple and effective way to provide quantitative assessment of ascending aorta calcium burden. There is an excellent intra-observer congruity with high reproducibility of measurements. This method may be particularly useful when screening optimal candidates for transcatheter aortic valve implantation.

* Correspondence: grescigno@me.com

${ }^{2}$ Cardiac Surgery Department, Ospedali Riuniti di Ancona, Ancona, Italy

Full list of author information is available at the end of the article

\section{Authors' details}

${ }^{1}$ Vascular Surgery Department, Ospedali Riuniti di Ancona,

Ancona, Italy. ${ }^{2}$ Cardiac Surgery Department, Ospedali Riuniti di Ancona, Ancona, Italy. ${ }^{3}$ Radiology Department, Ospedali Riuniti di Ancona, Ancona, Italy.

Published: 11 September 2013

doi:10.1186/1749-8090-8-S1-O20

Cite this article as: Gatta et al:: A simple and reliable tool to quantify calcium burden of ascending aorta. Journal of Cardiothoracic Surgery 2013 8(Suppl 1):O20.
Submit your next manuscript to BioMed Central and take full advantage of:

- Convenient online submission

- Thorough peer review

- No space constraints or color figure charges

- Immediate publication on acceptance

- Inclusion in PubMed, CAS, Scopus and Google Scholar

- Research which is freely available for redistribution
C Biomed Central 